Saudi Journal of Humanities and Social Sciences

Abbreviated Key Title: Saudi J Humanities Soc Sci

ISSN 2415-6256 (Print) | ISSN 2415-6248 (Online)

Scholars Middle East Publishers, Dubai, United Arab Emirates

Journal homepage: https://saudijournals.com

Original Research Article

\title{
Revitalization of Management of Diniyah Takmiliyah Madrasah in Cirebon City
}

\author{
Muchlis $^{1^{*}}$, Masyitoh $^{1}$, Khaerul Wahidin ${ }^{1}$, Diah Mutiara \\ 1Universitas Muhammadiyah Jakarta
}

DOI: $10.36348 /$ sjhss.2022.v07i01.002 $\quad$ | Received: 28.11.2021 | Accepted: 01.01.2022 | Published: 07.01 .2022

*Corresponding author: Muchlis

Universitas Muhammadiyah Jakarta

\section{Abstract}

This study aims to describe the results of the revitalization of the management of the Diniyah Takmiliyah Madrasah in the City of Cirebon which includes the mission and mission, learning, curriculum, facilities, and infrastructure of the diniyah takmiliyah Awaliyah and its relation to Islamic life. Systematic exploration of information. In particular, this research analyzes the management of Madrasah DiniyahTakmiliyah, especially the Awaliyah level, and its relationship to the Islamic life of the citizens of the city of Cirebon. The method used is qualitative, evaluative analytic with the function of providing a very deep essence of meaning for facts, data, and news which is a research scheme containing an outline starting from statements, reasoning, and finalizing data. The results achieved in this study are that it is necessary to 1) be carried out by formulating a good curriculum and learning and adapt to the needs of each MDTA which refers to "Rahmatan Lil 'Alamin". As the basis for the basic philosophical concepts of Islamic education 2) Carrying out updates on its objectives, contents, and teaching materials, by followers the rules of use to be used as the basis for implementing guidelines to achieve Islamic education goals that refer to the vision and mission 3) Performing teacher skills, media learning, learning methods adapted to the vision and mission of each MDTA 4) Implementing MDTA management carried out using existing management patterns and characteristics in the community and the ability to adapt to the local socio-cultural environment, with a formulation that includes planning, organization, leadership, and supervision. 5 improve skills, commitment, qualifications, and professionalism. 6) Renewal of place, incentives for teachers, and completeness of infrastructure.

Keywords: Revitalization, Management, MDTA.

Copyright () 2022 The Author(s): This is an open-access article distributed under the terms of the Creative Commons Attribution 4.0 International License (CC BY-NC 4.0) which permits unrestricted use, distribution, and reproduction in any medium for non-commercial use provided the original author and source are credited.

\section{Preliminary}

The current of modernization and information technology is increasingly developing in human life, with all its positive and negative impacts. These developments have brought human life to two important choices. First, modernization is a form of progress in life that must be addressed as a gift that can be used to develop human civilization. Second, modernization is a form of threat to life that must be wary of by humans, because it will bring damage to human civilization.

Thus, modernity on the one hand hurts civilization. One of them is marked by the increasingly visible dehumanization and decadence of the human dimension (especially morality-spirituality) in all lines of life without exception. Thus, it can be said that the progress of science and technology has not yet been able to fully lead mankind to the point of enlightenment and essential civilization of the times, namely peace and tranquility. (Faturahman, 2016: 57-94).

The achievements of modern civilization that have been achieved by humans through the creativity and sophistication of the technology that they have developed have secretly been in the dimension of the void of the meaning of human life itself.

They experience a kind of identity crisis that has penetrated all walks of life, which is often referred to as a "spiritual crisis" or some say an "existential crisis", or more precisely, experiencing a moral crisis. Indeed, it cannot be denied that modernity has brought advances in science and technology that encourage progress in other fields beyond what has been done by pre-modern human civilization. Modernity, modernity has helped humans a lot. 
Muchlis et al; Saudi J. Humanities Soc Sci, Jan, 2022; 7(1): 6-13

The mosque as a driving force for the surrounding community is a religious institution that is very close to the community. Adults and children are the worshipers in the mosque need appreciation in the form of activity. The establishment of MDTA in each mosque is a form of appreciation for the mosque to the community, especially in helping parents in educating their children's religion.

The contribution of the mosque is needed by the community, especially for the resilience and preservation of religious and moral values in the local community. Rasulullah saw. Our role model made the mosque the center of da'wah activities, including education, and fostering the people at that time.

Then in the era of KhulafaurRasyidin, the mosque was built magnificently side by side with buildings as the center of people's activities. The mosque was also built side by side with the campus. Mosques in Indonesia are like miniature mosques at the time of the Prophet Muhammad, the center for the development of the people. So that later it is hoped that it can improve or maintain its environment.

Then in the era of Khulafaur Rasyidin, the mosque was built magnificently side by side with buildings as the center of people's activities. The mosque was also built side by side with the campus. Mosques in Indonesia are like miniature mosques at the time of the Prophet Muhammad, the center for the development of the people. So that later it is hoped that it can improve or maintain its environment.

This regional regulation also provides contributions to MDTA in the form of grants in the form of teacher fees and MDTA facilities such as desks, mukena, which have been given since 2016 until now. This award is a form of government attention to MDTA.

The public's attention to the importance of religious education for their sons and daughters encouraged MDTA organizers to give their best. Parents do not regret spending money on education outside formal schools, because there is a high awareness of the importance of madrasas.

The presence of MDTA is a solution and a partner for parents in educating the main points of religion, namely moral education, aqidah, reading the Koran, praying, fasting, zakat. The presence of MDTA in the community is very helpful for parents in family diversity (Chadijah, 2020: 2-3).

The presence of MDTA is a solution and a partner for parents in educating the main points of religion, namely moral education, aqidah, reading the Koran, praying, fasting, zakat. The presence of MDTA in the community is very helpful for parents in family diversity. (Chadijah, 2020: 2-3).

According to Akbar, the practice of formal education in Indonesia tends to be oriented towards education based on technical skills or hard skills, as well as developing intellectual intelligence (IQ), while the soft skill abilities contained in emotional intelligence and spiritual intelligence are very lacking. The presence of non-formal educational institutions, one of which is called Madrasah Diniyah, is here to facilitate the development of students' spiritual intelligence. Madrasah Diniyah is a non-formal educational institution that teaches Islamic values. These Islamic values are contained in the fields of study that he teaches such as Fiqh, Tawhid, Akhlaq, Hadith, Tafsir, and other lessons that students do not get when studying in formal schools that are not madrasas (Akbar, 2009).

Educational institutions must appear to be the pioneers of character education. Character education must be socialized, internalized, and intensified from an early age at all levels of national and state life. This is due to the strategic role of education as a non-formal institution that is responsible for producing and preparing quality future cadres in the fields of Islamic, moral, and spiritual knowledge. Educational institutions must work together with families, communities, and elements of other nations to realize a grand agenda of instilling strong character in students. (LailatulIzzah, 2019:85).

Madrasah Diniyah is a religious education institution on the outside of school which is expected to be able to continuously provide Islamic religious education to students who are not fulfilled on the school path given through the classical system and apply education levels. Diniyah Madrasas are madrasas where all subjects are religious sciences, namely fiqh, interpretation, monotheism, and other religious sciences.

Complete religious material, it allows the students who study in it to better master the religious sciences. Madrasah Diniyah is an educational institution that provides classical education and teaching in Islamic religious knowledge to at least 10 or more students together, including children aged 7 (seven) to 18 (eighteen) years. (Latif, 2018:12-15).

The process of developing a learning program implies that the head of MDTA requires certain efforts in playing his role which is not only built based on his authority as a learning leader but also based on his responsibility to bring students to understand the values of Islamic teachings and have good morals. Therefore, the guidance for students carried out by the head of MDTA must be interpreted as part of the Islamic 
Muchlis et al; Saudi J. Humanities Soc Sci, Jan, 2022; 7(1): 6-13

religious learning process to respond to the demands and needs of the Muslim community, especially the Muslim community of Cirebon City.

For this reason, the response to these demands and needs becomes even more relevant when faced with the demands of Cirebon City Regional Regulation No. 10 Th. 2013 regarding Madrasah DiniyahTakmiliyahAwaliyah (MDTA) education, wherein article 5 it is stated that the implementation of DiniyahTakmiliyah Education in the City of Cirebon aims to provide students with knowledge and abilities to carry out ad dinul Islam in life and daily life. Based on the explanation, the problem is formulated as follows:

1. How is the revitalization of Strategic Management and Islamic Management at MDT?

2. How is the revitalization of MDT management implemented?

3. What are the benefits of revitalizing management and learning and development in MDT and the benefits for the community?

\section{METHOD}

The method used in this research is analytical descriptive, which is a research method that presents data by the reality as it is without any element of data manipulation, by prioriizing data systematically as the main goal, both in terms of facts and characteristics, objects and subjects that are carried out neatly and precisely Target. This method can also get variations in problems related to human behavior and education patterns.

By describing the data according to reality, it is managerial in developing tendiks performance to improve the quality of existing education.

\section{RESEARCH RESULTS AND DISCUSSION \\ A. Profile of Madrasah \\ DiniyahTakmilliyahAwaliyah (MDTA) in Cirebon City}

The scope of the Cirebon City area, the existence of Madrasah DiniyahTakmiliyahAwwaliyah (MDTA) are influenced by many factors. Geographical location, community culture, organizers, conditions of teachers and students, as a whole have a significant impact on the management and implementation of the Islamic religious learning process.

The quality of the Islamic religious learning process can be realized properly if it is supported by four main elements, namely management, facilities or infrastructure, teacher conditions, and student conditions. These four elements become a unified learning system (learning system) that is integrated that can establish a relationship between goals and learning in which there is an interactive relationship. In other words, the instruments in KBM, such as planning the teaching system, preparing learning materials, methods, learning content (content), objectives, types of assessment, and teaching strategies are closely related to the actualization of learning in achieving its goals. The combination of the learning system with the teaching components will shape the conditions for the Islamic religious learning process. Here is the schematic.

Based on data included in the EMIS (Education Management and Information System) of the Ministry of Religion of Cirebon City, in the $2019 / 2020$ school year the number of MDTA in Cirebon City were 83 institutions, with the following distribution;

The findings in the field using the DiniyahTamilliyahAwaliyah (MDTA) curriculum follow the Ministry of Religion curriculum, but the curriculum is usually developed according to the DiniyahTamilliyahAwaliyah (MDTA) conditions of each DiniyahTamilliyahAwaliyah (MDTA). Only a small number have their own specific curriculum. It can be concluded, in general, that it still focuses on the content of the curriculum itself and has not led to other aspects, such as the syllabus and lesson plans.

For the evaluation of learning carried out, the research findings found that the evaluation of learning carried out by DiniyahTamilliyahAwaliyah (MDTA) in Cirebon City generally followed the evaluation system held by the Pontren Section of the Ministry of Religion of Cirebon City, both regarding time, type, and technical evaluation.

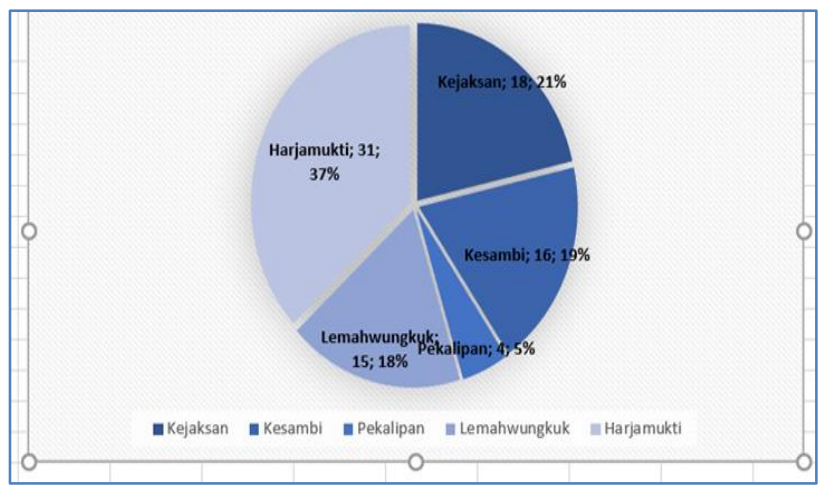

Fig-4.1: Distribution of Total DTA in Cirebon City

The administrative system implemented at MDTA adjusts to the ability of the manager in this case the Principal. General administration, finance, student affairs, personnel, and academics. Even in some MDTA, student recruitment without registration forms, the important thing is that children want to learn even if they are not registered with their parents. Children come to MDTA alone to learn and most of them just follow their peers who are already MDTA students. 
Muchlis et al; Saudi J. Humanities Soc Sci, Jan, 2022; 7(1): 6-13

This finding can interfere with the conduciveness of the learning process because in general, model children tend to be less active in participating in learning activities. Based on the research sample, the number of MDTA teachers and students in Cirebon City is as follows:

PERBANDINGAN JUMLAHDTA, GURU DAN MURID

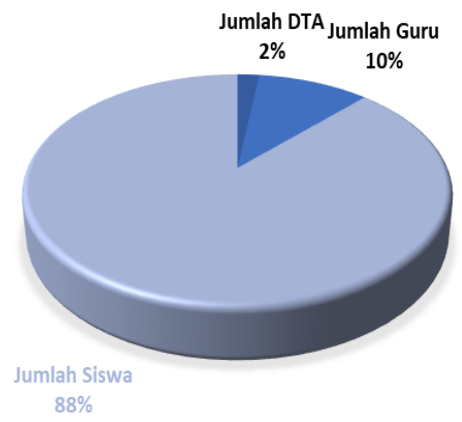

Fig-4.2: Comparison of the Number of MDTA, Teachers, and Students in Cirebon City

Source: Ministry of Religion, Cirebon City, Results of Bleaching Tables for 2019

Figure 4.2. Indicates the occurrence of fluctuations in the number of students in each MDTA. The proof, the number of students in each class is not stable. According to the informant, the instability was triggered by many factors, including the lack of motivation to learn and minimal parental support. Students' learning motivation and parental support are both weak, thus affecting the conduciveness of the learning process at MDTA.

In addition, in MDTA where there are no students in the class, it is indicated that the implementation of the learning process is not running properly, in an important sense the learning activities are running while the grading and achievement of learning objectives are not the main goal.

The comparison of the number of teachers is 214 and the number of students who must receive excellent learning services so that there is no shortage of teachers to teach in each class.

\section{B. Barriers to Revitalization in MDTA Cirebon City}

The obstacles to the learning process at MDTA in Muhaimin's view (2001:29) involve 3 (three) things, namely; 1) the implementation is less professional, 2) the learning is trapped in classical literature so that it is less able to develop Islam in contemporary problems, and 3) there are signs of drifting away in the search for status and formal legitimacy rather than a religious call. Learning in MDTA is disoriented, even in some cases experiencing a slump, such as the lack of teachers, limited learning facilities, learning that is less interesting and not conducive, lack of learning resources, and limited learning time.

This problem is exacerbated by the absence of a clear curriculum. As a result, the learning process runs without a clear direction and the graduates are also of low quality. According to WahyuNurrohim, PAI instructor at the Attorney General's Office, (interview, $28 / 5 / 2018$ ), such conditions are generally caused by a lack of public attention and the support capacity of the local government in providing MDTA education, resulting in low quality of education, including the quality of the learning process. Local governments seem half-hearted in paying attention to MDTA. Even though the City of Cirebon already has a legal umbrella for the local regulation on diniyah, which should be maximized to make a positive contribution to the people of the City of Cirebon.

Maximizing this local regulation can encourage MDTA to become more alive and develop so that Islamic religious education in the city of Cirebon will be livelier and in the end the aspirations of the Cirebon City Government to realize a religious and religious city come true. Facts on the ground show that, although the local regulation on DiniyahTakmiliyah should have been intended for MDTA to encourage learning process activities, it is not on target so that MDTA becomes sluggish again. Lethargy from enthusiasts, learning process activities, and even sluggishness to rise towards quality education.

This sluggishness is as illustrated in the implementation of MDTA in Pekalipan District. OtongTumari as the MDTA coordinator of Pekalipan District told that the cases that occurred in Pekalipan District; Of the 4 DTA institutions in Pelipan subdistrict, only 1 DTA, namely Baiturrahim, exists in the sense of being diligent in providing monthly reports and participating in learning evaluation activities, the rest are vacuum What obstacles and obstacles are faced in revitalization.

The problem of the internal learning process in MDTA is the result of the lack of encouragement from the community and the local government. According to Abdul Goni (interview, 30/5/2018), the problem with the learning process that occurs internally at MDTA is not simply a lack of government support, but many factors that cause the learning process to become problematic, including:

1. The unwillingness of the institution to follow the rules so that it tends to be careless in carrying out learning.

2. Tend to be closed, in the sense of not wanting to accept creativity and innovation.

3. Many MDTA heads do not understand learning management. 
Muchlis et al; Saudi J. Humanities Soc Sci, Jan, 2022; 7(1): 6-13

4. Lack of support from parents/guardians and local governments towards the implementation of learning in MDTA, especially the problem of financing.

5. There are still many MDTAs in Cirebon City which are free of charge without charging any fees.

\section{The results of the findings of this study are}

1. Not all MDTA has a Vision and Mission that refers to the formation of an Islamic society. Meanwhile, the steps taken by MDTA to achieve the vision and mission through the curriculum at MDTA were not well socialized and understood by the MDTA management. Therefore, it is necessary to develop the vision and mission of each MDTA in the face of modernization and changes in globalization.

2. The curriculum used in MDTA in general still uses the product curriculum of the West Java Provincial Ministry of Religion, namely the 2010 curriculum with a study period of 6 years, while the concepts and curriculum of the Ministry of Religion for Central Products have a study period of 4 years. There is a difference in the level of the length of the study period.

3. There is no uniformity of the MDTA curriculum in Cirebon City, so the existing MDTAs run independently according to their understanding of the curriculum based on the assumptions of each institution.

4. MDTA throughout Cirebon City already has learning process documents (Education Calendar, Teacher Handbook, Teacher and Student Attendance List, learning media and class journal books, and other documents) that have been provided by the institution, however in its implementation it is not optimal, often neglected, because the existence of these documents has no impact on the recipients of their rights in carrying out their obligations, one of which is that there is no reword to their teachers, so teachers are lazy to fill out these documents.

5. There are some MDTA heads do not understand MDTA management, one of which is the importance of RPP for teachers as an instrument in their learning activities, but they are often ignored and not implemented for the important reason that MDTA activities run, regardless of quality or not, because they are considered to have no salary (honor). It can be seen that the main problem of MDTA in Cirebon City is financial problems which result in the inability of teachers to prosper so that it has an impact on the low quality of the learning process.

6. In the management of MDT teacher recruitment, it is often random and the average MDTA teacher in Cirebon City has weak motivation and commitment to teaching. This is because the welfare of teachers is around Rp. 25,000 to Rp. 50,000 a month, even if some are not paid at all. This condition causes teachers not to focus on teaching, preferring other activities that are more promising, with the unloading of teachers this has an impact on the quality of management that uses the principle as long as there are teachers who want to teach without any commitment from the start. So it is less creative and innovative in teaching. And some use the package model of MDTA teacher recruitment, one of which is given the task of teaching in the morning at RA/TK then in the afternoon teaching at MDTA for reasons of operational costeffectiveness.

7. The backgrounds of MDTA teachers vary, some are graduates of Islamic boarding schools, Package C, SMP, SMA, MA/MAN, D2, S1, and even Masters.

8. The management of MDTA in Cirebon City is carried out using the existing management patterns and characteristics in the community. These patterns and characters on the one hand describe one's abilities with the local social-cultural environment, but on the other hand, do not describe current and long-term abilities. There is a need for an empowerment formulation that includes planning, organizing, leadership, and monitoring of MDTA in Cirebon City.

9. The Revitalization Model of MDTA Management and Its Relation to the Islamic Life of the Cirebon City Residents is evidenced by the finding that most children who participate in MDTA change their life behavior, both in manners, morals , and consistency in worship, which are more diligent and contribute and give new colors in forming a society that is Islamic.

10. There is still little support from the local government regarding the honorarium for MDTA teachers and institutional facilities, parents do not support activities that support success in learning, many principals and teachers still do not understand learning management in MDTA. And there are still many free MDTAs at no charge.

\section{REFERENCE}

- -------------- dan Udin Syaefudin Sa'ud. (2005). Perencanaan Pendidikan. Bandung. PT. Remaja Rosdakarya.

- $\quad$---------------. (1985). Teaching The Gifted Child. Boston: Allyn\& Bacon.

USA: Mac Millan.

- - ----------. (1998). Educational in Indonesia: From Crisis to Recovery. Educational Sector Unit East Asia and Facific Regional Office.

- --------------. (1999). Pengawas Sekolah dan Pengelolaan Sekolah. Makalah pada Diklat Calon Pengawas Sekolah. Bandung: Kanwil Depdiknas Propinsi Jawa Barat. 
Muchlis et al; Saudi J. Humanities Soc Sci, Jan, 2022; 7(1): 6-13

-------------------. (2000). Kumpulan Materi Seri Perencanaan Pendidikan. Bandung. PPS. UPI.

ProfilMadrasah Masa Depan.Jakarta. Bina Mitra PemberdayaanMadrasah.

Pengembangan Ciri Khas Islam. Jakarta. Bina Mitra PemberdayaanMadrasah.

- . (1997). Pedoman Perencanaan Taktis. Jakarta: Prenhallindo. (1997). Pedoman Pemikiran Strategis. Jakarta: Prenhallindo.

- Abdul , R. S. (2005). PanduanPerencanaan dan PengembanganMadrasah. Jakarta. Bina Mitra PemberdayaanMadrasah.

- Abdullah, T. (1971). School and Politics: The KaumMudaMovenment in West Sumatra, Ithaca. Cornell University.

- Achmad, S. (1988). Sistem Manajemen Penididikan di Indonesia.Bandung: IKIP.

- Adib, $\mathrm{N}$.

KebijakanTentangPengembanganLembagaPendidi kan Islam Non formal: MadrasahDiniyahTakmiliyah (MDT) Tahun 20112015. JurnalIlmiahSustainable, Vol.2 No.1

- Agustinus S. Wahyudi.

(1996).

ManajemenStrategik:

PengantarProsesBerpikirStrategik.

Jakarta:

BinarupaAksara.

- Alfi, Syahr, Z. H. (2016). Membentuk Madrasah Diniyah Sebagai Alternatif Lembaga Pendidikan Elite Muslim Bagi Masyarakat. Jurnal Intizar, 22(2).

- AzraAzyumardi. (2000). Pendidikan Islam Tradisi dan ModernisasiMenujuMileniumBaru. Jakarta: Logos WacanaIlmu.

- Banghart and Trull. (1973). UNISCO.

- Bogdan, Robert and Biklen. (1992). Qualitative Research For Education: An Intruduction to Theory and Methodes. Boston: Allyn and Bacon. Inc.

- Bryson, J, M. (2001). Strategic Planning For Public And Nonprofit Organizations: A Guide DtrangtheningangSustainning Organizational Achievement. M. Miftahuddin (penerjemah). PerencanaanStrategisBagiOraganisasiSosial.

Yogyakarta PustakaPelajar.

- Buttler. F. Coit. (1972). Instuctional System Development for Vocational and Technical Training. New Jersey: Educational Technology Publication. Inc.

- Castetter, B. William. (1996). The Human Resource Function in Educational Administration. Ohio: Merril an Imprint of Prentice Hall.

- Charles, P. (1965). The Quality Management. New York: John Wiley \& Sons.

- Cheribgton, David, J. (Organizational Behaviora). "The Management of Individual and
Organizational Performance”. USA:

MasshusettAllyn\& Bacon.

- Coleman, T., \& Marrianne. (tt). Leadership and Strategic Management in Education. London; Paul Publishing Ltd.

- Cravens, D. W. (1972). Strategic Marketing. USA Prentice-Hall International.

- Danim, S. (1998). Model Pengelolaan Terpadu Sistem Pendidikan Tenaga Kependidikan. Disertasi pada PPS UPI. Bandung: Tidak diterbitkan.

- Davis, R.G. (1980). Planning Education for Development: Volume Issue and Problems in The Planning of Education in Developing Coutries. Cambridge, Massachusetts.

- Deming, W. Edwards. (1986). Out of Ceisis, Massachusetts Institute of Technology, Center for Advenced Engineering Study. Boston: Massachusetts.

- Depag. R.I. (2003). DesainPengembangan Madrasah Visi 2006. Jakarta. Dirjen Madrasah danPais.

- Depag. R.I. (2003). KebijakanStrategis. Jakarta. DirjenKelembagaan Agama Islam.

- Depag. R.I. (2003). Sistem Perencanaan. Jakarta. Dirjen Kelembagaan Agama Islam.

- Djaman Satori. (1989). Pengembangan Model Supervisi Sekolah Dasar. Bandung: IKIP Bandung.

- Djaswidi, M. (2003). Strategi Pengembangan Model Kepemimpinan Trasformasional Kepala Tsanawiyah (Penelitian dan Pengembangan Kepemimpinan Kepala MTs Negeri di Kabupaten Ciamis Provinsi Jawa Barat). Desertasi. Bandung PPS UPI

- Dubrin, A.L. (1994). Essesntial Management. Los Angeles, Ken Publishing Coy.

- Dunn, William. N. (1998). Public Policy Analysis: An. Introduction. SamodraWibawa, dkk (penerjemah) PengandarAnalisisKebijakanPublik. Yogyakarta: Gadjah Mada Univiversitas Press.

- Edward, B. Fiske. (1988). Arah Pembangunan Desentralisasi Pengajaran. Politik dan Konsensus. Jakarta: Grasindo.

- Engkoswara. (1987). Dasar-Dasar Administrasi Pendidikan. Jakarta: LP2TK.

- $\quad$ Erihadiana, M., Chadidjah, S. (2020). Manajemen Peserta Didik Pada MDTA Al Wahda Terunggul di Kota Bandung. Jurnal Manajemen Pendidikan Islam. Vol.5 No.2.

- Fahrurrozi. (2003). Perencanaan Strategik dalam Pendidikan Islam(analisis dan Perencanaan Pengembangan Pendidikan di Ma'had Tahfihz al Qur'an al Amin Prenduan Sumenep Madura. Yogyakarta; IAIN Sunan Kalijaga (tidak diterbitkan)

- Fakry Gaffar. (1985). Kepemimpinan Pendidikan. Bandung: IKIP.

- Fattah, N. (2000). Manajemen Berbasis Sekolah. Bandung: CV. ANDIRA 
Muchlis et al; Saudi J. Humanities Soc Sci, Jan, 2022; 7(1): 6-13

- Fauzi, A. (2016). Pelaksanaan Pendidikan Madrasah Diniyah Di Kota Serang. JurnalPendidikandanKebudayaan, Vol. 1, Nomor 2.

- Feaach, F. (1994). Better Management Benefits Everyone. Education Views.

- Feldhuse, John. (1989). Execellence in Educating The Gifted. Colorado: Love \& Son LTd.

- Fikri, LutfiNajamul. (2017). DinamikaPeninjauanKurikulum Madrasah DiniyahTarbiyatulAthfal (MDTA) Gontor. Jurnal Muslim Heritage, 1(2).

- Furqon. (1999). StatistikaTerapanPenelitian. Bandung: Alfabeta.

- Goesthsch., \& Davis. (1994). Introduction to Total Quality: Quality, Productivity, Competitiveness. Englewood: Prtentice Hall.

- HadariNawawi. (1981). AdministrasiPendidikan. Jakarta: GunungAgung.

- Harling Paul. (1984). New Directions in Educational Leadeship. The Falmer Press.

- Harsey, P., \& Kenneth, H. Balanchard. (1988). Management of Organizational Behavior. New Jersey: Engewood Cliffs.

- Hasanah, F. (2016). Problem PengajaranMenulis Arab Pegon Di Madrasah DiniyahTakmiliyahAwwaliyah (MDTA). TesisPendidikanBahasa Arab. UniversitasPendidikan Indonesia.

- Hasbullah. (2006). OtonomiPendidikan. Jakarta: Raja GrafindoPersada.

- Ishkawa, K. (1986). Guide to Quality Control, Asian Productivity Organization. New York: UNIPUB.

- Izzah, L. (2019). MenumbuhkanNilai-Nilai Anti KorupsiPadaAnakUntukMembentukKarakterMelal ui "Semai Games" Di MDTA RabithatulUlumPekanBaru. JurnalPsychoplytan, 2(2).

- James W. Guthie and Rodney. (1991). Educational Administration and Policy. Effectife Leadership for Amiracan Education. Second Edition. Massachutesetes: A Division of Simon \& Schuster.

- Juran, J., \& Gryan, F, M. (1980). Policies and Objactives. Quality Planning and Analysis. New York: MCGraw-Hill.

- Kast, F.E., \& Rosenzweig J.E. (1995). Organizations Structure, Processes, Behavior. Jakarta: BinaAksara.

- Maimun Ach, Fathor Rachman. (2016) Madrasah Diniyah Takmiliyah (MDT) Sebagai Pusat Pengetahuan Agama Masyarakat Pedesaan (Studi Tentang Peran MDT Di Desa Gapura Timur Gapura Sumenap). Jurnal Anil Islam. Vol.9. No.1.

- Makmun, Tb. AbinSyamsuddin. (1999). AnalisisPosisi Pembangunan Pendidikan. Jakarta: Biro PerencanaanSekjenDepdiknas.

- Malik Fadjar, (1998). Visi Pembaharuan Pendidikan Islam. Jakarta. CV. Alfa Grafikatama.
- Manullang, M. (1996). Dasar-dasar Manajemen. Jakarta: Ghalia Indonesia.

- Michael, F. (1992). The Future Educational Change. The Meaning of Educational Change.Ontarion: OISE Press.

- Moleong, L.J. (1985). Metodologi Penilitian Kualitatif. Bandung: Remaja Rosdakarya.

- Morrisey, G. L. (1997). Pedoman Perencanaan Jangka Panjang. Jakarta: Prenhallindo.

- Muhammad, S. (2000). Manajemen Strategik Konsep dan Kasus. Yogyakarta: UPP AMP YKPN.

- Muhira, L. (2020). Peran Madrasah Diniyah Takmiliyah Awaliyah Dalam Pembentukan Mental Anak Yang Berakhlakul Karimah. Journal Jendela Bunda PG PAUD UMC. Vol 8. No.1.

- Mulyasa, E. (2003). PedomanManajemenBerbasis Madrasah. Jakarta. Dirjen Kelembagaan Agama Islam.

- Nawawi, H. (2000). Manajemen Strategik Organisasi Non Profit Bidang Pemerintahan. Yogyakarta: Gadjah Mada University Press.

- Nizah, N. (2016). Dinamika Madrasah Diniyah Sutu Tinjauan Historis. Jurnal LPPG (LembagaPeningkatanProfesi Guru. Vol. 11, No. 1.

- Nurrochmat, Dodik Ridho. (2006). Mengintegrasikan Aspek Lingkungan dan Aspek Ekonomi Dalam Kebijakan Pembangunan. Jakarta: Departemen Kehutanan.

- Philips B. Crosby. (1990). Managing for Total Quality. New York: Prentice-Hall.

- Qodri A. Azizy. (2003). Pendidikan (agama) UntukMembangunEtikaSosial. Semarang. CV. Aneka Ilmu.

- Richad, A. Gordon. (1976). School Administration: Challenge and Opportunity for Leadership. Iowa: Wm C. Brown Company Publisher.

- $\quad$ Robert, W. Terry. (1993). Autentic Leadership. San Fransisco: Jossey Bas Publisher.

- Roger, S. (1994). School Based Management. School Talk Magazine.

- $\quad$ Ronal W Rebore. (1985). Educational Administrasi A Management Approach. New Jersey: PrenticeHall. Inc.

- Ronald T. Hyman. (1975). School Administrato's Handbook of Teacher Supervission and Evaluation Methods. New Jersey: Prentice-Hall. Inc.

- Rosnita. (2018). EvaluasiPembelakjaran Di Madrasah DiniyahTakmiliyahAwaliyah Al Washliyah Di KabupatenBatu Bara. JurnalMiqot. Vol XIII. No.2.

- Rowley, R.P., Lujan H. D, danDollence M.G. (1997). Strategic Change in Colleges ang University, San Francisco, Jossey-Bass Publishers.

- Rue, Leslie, W., \& Halland, Phyllis G. (1989). Strategic Management: Concepts and Experiences. Singapore: McGraw-Hill International.

- Sallis, E. (1993). Total Quality Management in Education. London: Philadelphia. 
Muchlis et al; Saudi J. Humanities Soc Sci, Jan, 2022; 7(1): 6-13

- Satori, Djam'an. (1999).

PerencanaanPendidikanMakrodanMikro. Jakarta: Biro PerencanaanSekjenDepdikbud.

- Scott, K., \& Walker, A. (1995). Teams: Teamwork and Team Bulding. Singapore: Prentice-Hall.

- Sergiovanni, T. J. (1992). Moral leadership. San Francisco, CA: Jossey-Bass.

- Sergiovanni, T. J., Burlingame, M., Coombs, F. S., \& Thurston, P. W. (1987). Educational governance and administration $\left[2^{\text {nd }}\right.$ ed.]. Englewood Cliffs, NJ: Prentice-Hall.

- Singarimbun, M dan Effendi, S. (1981). MetodePenelitianSurvai. Jakarta: LP3ES.

- Sismono.

(1991). SejarahdanAmalBahaktiDepartemen Agama Republik Indonesia. Bandung. PenerbitBinaSiswa.

- Sjarief, D. (1999). PerencanaandanPenerapannyaDalamManajemenStr tagik di PerguruanTinggiSwasta, KajianEmpirikterhadapPerencanaanSebagianKonse pManajamenStrategik di PerguruanTinggiSwasta (Kasus PTS Jawa Barat, Desertasi. Bandung. PPS IKIP.

- Soewarso. (1996). Total Quality Management. Yogyakarta: ANDI.

- Spansbauer, J.S. (1992). A Quality System for Education. ASQC. Quality Pross.

- $\quad$ Steers, R. M. and Porter, L. W. (1991). Motivation and Work Behavior. Singapore: McGraw-Hill International.

- $\quad$ Stephen, K. (1969). Administration of Technology The Schools Executive. Washington DC: ASSA.

- Stogdill, Ralph, M. (1978). Handbook of Leadership. London: Coller Mac Milian Publisher.

- Stoner, J. A. F., Freeman, R. E. (1995). Manajemen.Jakarta:PT. Prehallindo.

- Sugiyono. MetodologiPenelitianAdministrasi. Bandung: Alfabeta.

- Sumarno. (1988). Strategi Pembangunan Pendidikan dan Kebudayaan.Jakarta: Depdikbud, DirjenDikti.
- SupandidanachmadSanusi (1988). KebijakandanKeputusanPendidikan. Jakarta: Depdikbud, DirjenDikti.

- Surachmad, W. PengantarPenelitianIlmiah. Bandung: Tarsito.

- Syafiie, A. (2002). Strategi Model Pengembangan Madrasah AliyahKeagamaanUnggula (StudiKasusEksplorasidan Model Pengembangan Madrasah Aliyah Keagamaan).Desertasi. Bandung. PPS UPI.

- Thomas, J. A. (1970). The Productive School, A System Analisys Approach, to Education Administrasi. New York: John Willey \& Son, Inc.

- Tilaar, H. A. R. (1999). Beberapa Agenda RepormasiPendidikanNasionalDalamPerspektif Abad 21, Mageleng. Indonesia Tera.

- Tim PenelitiDepag. (2000). KajianPengembanganTerhadapPembinaanPendidi kanpada Madrasah (StudiKebijakanPembinaan Madrasah Era DesentralisasidanOtonomi Daerah). Jakarta. Departemen Agama RI. BadanPenelitiandanPengembangan Agama.

- UaAbung. (2001). Problematika Madrasah. Jakarta. Dirjen Kelembagaan Agama Islam

- Wahab, RochmaddanAnantoKusuma Seta. (1988). Analisis Stakeholder Pembangunan PendidikandanKebudayaan.Jakarta: Depdikbud Biro PerencanaanSekretarisJenderal.

- Wayne K. Hoy., Ceci I G. Miskel. (1978). Educational Administration Teory. Risearch and Practice. New York:Random House.

- Vembrianto, St. (1985). PengantarPerencanaanPendidikan. Yogyakarta: YayasanPendidikanPramita.

- Wheelen, Thomas L. and Hungger, J. Davis. (1995). Startegic Management and Bussiness Policy, Singapore, Addison Wessley.

- Wijaya. (2001). Statistik Non Parametrik (Aplikasi Program SPSS). Bandung: Alfabeta.

- Word Bank Study. (1997). Indonesia Suggested Priorities for Education. Population and Human Resources Division. 